\title{
Bringing Mindfulness to the K-6 Classroom
}

\author{
Barbara Kurtzman
}

\begin{abstract}
In this interview, elementary school teacher and mindfulness coach Barbara Kurtzman discusses how she brought mindfulness in the class, starting in Cycle 1 and then with the whole elementary school. Her interest in mindfulness began as a personal journey which she wanted to share with her students. She explains that taking only a few minutes a day helps her and her students to be more focused on the task at hand. She has found that her students also use mindfulness outside of her classroom. She finishes by giving advice to teachers who are interested in including mindfulness in their classrooms.
\end{abstract}

How would you define the mindfulness practice that you use in your classroom?

It's a great question because there's so many ways to define "mindfulness" and for me I really had to think about that question when I was bringing it into the classroom. I really wanted students to stop and breathe. And when I asked people around me, "When was the last time you took a breath?" (not the students themselves, but just people in my own world), they would stop and look at me: What a strange question. We're breathing now, we breathe all the time... of course, we breathe. But I said, "When was the last time you stopped and you consciously took a breath?"

I started off this practice doing yoga with my students. So about four years ago I would use yoga in the classroom, where we would push all the desks aside and we would find 15-20 minutes to do yoga. I realized that there was something that wasn't going right with that. And, in fact, I went to get trained in teaching yoga because I see myself as a teacher of reading, writing, math, problem solving, critical thinking... how was I going to justify that I could teach yoga? After being trained in yoga for childrenwhich is different than doing it with adults - I realized that it was the end of a yoga practice, which is what I wanted to bring to my students. And like any other subject that I'd been asked to teach—reading, writing, any other content-I realized I had to immerse them in the text, and the text was to breathe and to be conscious of breathing.

And that's basically what we do. So once a day, and I take the opportunity after lunch, after recess, when I meet them downstairs in a very loud crowded locker room, all I say to my afternoon students is: "Go upstairs, go in your mindful position." And then I'm the last one to come into the room. And I have to tell you that I do it as much for them as I do for myself because these children have been in working with their French teacher all morning and then they come to me in the afternoon. They have to "perform" as they did in the morning and children learn differently at different times. We take the time-we stop consciously - and we go through a mindful practice that I can explain to you more about what it exactly looks like and sounds like. 
How did you explain to the children the need to be mindful of their breathing?

I didn't. I showed them instead of telling them. On the very first day, day one, they walked into class and I said, "Girls, we're going to do mindfulness" and they did have some experience last year in kindergarten. Last year I initiated what was called the "30-day mindful journey" and it happened with the whole school. Every child from kindergarten to grade six for the month of November...their teachers committed to one minute of stopping to breathe. We talked about what does it mean to be present and what does it mean to be grounded and we sort of defined some of the words that are used around mindfulness. We called it our mindfulness practice and it went on from the first of November to the $30^{\text {th }}$ of November.

This year, when I had those same kids in grade one, the very first day, I said, "We're going to continue your mindful practice, but we're going to commit to it every day." I had six children that said, "I don't want to." I do it with my French Grade 1 colleague-it goes on in French as it does in English-and she looked at me and said, "What are we going to do?" And I said: "We're going to go on. We just show them what to do. We just demonstrate." I keep my eyes closed during it, so I didn't see what was going on, but that's part of being mindful: You hear the sounds around you, you acknowledge them, but you continue staying present in the moment. It's like magic_-it reminds me of teaching reading in grade one. They come in and they're so excited to read, but they're scared. They're good storytellers, but reading the words on the page is so foreign to them. I think they come into grade one...they understand that letters make sounds, sounds make words, and words make sentences, but they haven't practiced it.

Mindfulness is just another practice and the results are incredible. It doesn't take long where you start seeing it and it doesn't happen every day. I tell the girls that too. Some days when you do your mindfulness practice you'll feel better than other days. Some days you really get the results right away and other days you have too many things on your mind so you can't really become mindful. But I tell them not to empty their minds, just to turn inward and stay present and in the moment and focused during the time of mindfulness. They still think it's one-minute long, but it's gone to about three or four. I don't take charge of when it ends-I've relinquished that leadership to the others.

Every week a new child is a mindful leader and they have a routine that they do with a rain stick and chimes—so, they in fact will end the session. If it rings too fast, I don't say anything... I just go with it. But I had to model it and when I was ready to have that gradual release of responsibility, we have it now as a class job. It's a very popular class job and it goes on for a week so children have that opportunity to be that mindful leader-and they are leaders because my hope and prayer is that, like I do lifelong learners for reading, I'm hopeful that they take this practice with them into the other grades. It's not part of everyone's curriculum - it is part of my curriculum, but it doesn't stop me from doing everything else... it's three minutes in a day. When I hear people say, "I don't have time," that's the part that makes me feel sad. I have said to my students: "In the future if you go into a situation where the person who is in charge says, 'there is no time' you can do it yourself. No one's going to know you're doing it. You're not tuning out; you're tuning inward." My hope and prayer is that they take this practice with them forever. 
The feedback I'm getting from parents is really interesting. I was afraid of parents a little bit because, like with anything else (like when that math program "Défi Math - Challenging Math" came into our curriculum) because parents weren't used to learning that way. I didn't want them to think that children were coming home and bringing a religious practice-there's absolutely no religion that I bring to this practice whatsoever. They've learned terms like Namaste, which means "may the light that shines inside of me shine onto you." And they use that, but it's not a prayer-it's just a way to close the practice. Parents are amazed at how children have been coming home and saying: "Can we do it as a family?"

Two things have sort of prompted it. This is a mind jar and every child made one this year in my class. It's just a symbolic representation of our mind. When children are coming upstairs to my classroom after recess and lunch and conflict resolution (things that have been solved and things that haven't been solved), our minds are like this. You shake up your mind jar and you put it in front of you, and it takes about a minute...we've timed it. We had to figure out the scientific recipe of different materials to put in...it takes about a minute for the sparkles to completely settle down. It's a symbolic representation of our minds and our brains. They brought that home, so that was kind of the text that went home with each child. Every child leaves it somewhere in their home and they use it.

When you first start with the children, how do you explain to them the importance of being grounded and turning inward? What do you tell them?

There is great literature and great illustrated picture books that are out there. I started off beginning the year reading them. For instance, one is called, "What Does It Mean to Be Present?" The way it's written in the book and it's written for that audience...children between the ages of...they really associate with it. They really start learning the vocabulary and they see a little girl in the story or a little boy who is modelling mindfulness. There is one book called, "The Moody Cow That Meditates," and in fact inside that book is a recipe for the mind jar. They start associating and relating to the text and they're making that text-to-self connection. It's not just me that says, "This is what it means." I use illustrated picture books a lot in my classroom - that's how I teach. It's not a foreign thing for me to teach them something through a text. Then, of course, they want to bring the books home-and they're just adorable, there's an excellent collection of books, written for children. I've read many and, like any other book, I won't read a book to my students that I haven't read myself first.

You said you've seen so many interesting results. What are they, tangibly?

I've been teaching for over 25 years and I've seen the complexity of students. They come in with so much, I'm going to call it "baggage," but it's not a negative thing. They come in also very programmed. Their days are programmed. They come to school from 8:00 until 3:00, and then after school they have extracurricular activities like ballet, jazz, sports, and they may not get home until the evening. They almost don't know what to do with their time when they have it. They almost look to me to feed them: "What's next?" And that has decreased so much because I see them even when they're doing their work, 
they're able to focus on what's in front of them. And sometimes I'll just say to them something like, "Are you focused?" and the word focus means something to them. I say to them: "Are you being mindful; are you in the moment?" Sometimes they'Il come up and they'll ask me a question and I'Il say, "Does that have anything to do with what we're doing right now? Are we being present?"

The words start to really mean something to them individually and the amount of time that these six-year-olds are able to focus on a task is incredible. And I've seen an increase from the beginning. They're leaving nap time in kindergarten. So, in fact, that is their mindful time. But the difference between nap time and mindfulness is that this is being labeled, and we talk and it's conscious. They know why they're doing it. I don't know if nap time is explained. They stop doing nap time when they're old enough, but I hope they never stop taking time to be mindful. I do some talking during it sometimes, my own talking, and I'm trying to teach them compassion and gratitude through mindfulness.

They are very respectful in this classroom. This classroom is a safe zone. They know when they walk in there's certain expectations and respect is number one, but I want to see it outside the classroom. I need to see that the transfer of knowledge is happening not just in this safe space, but in others. So sometimes I have to wait and I have to be patient. I may not see a child benefitting immediately in front of me. I see it, but the real benefit might happen years later. I have to just be patient and know that I'm giving them a skill and for those children who didn't want to do it on day one, they're my best practitioners.

Why do you think that is so?

Because they feel it. They don't have to be told that it's working; they feel it from inside out. And it's that Namaste, that light that shines, from the inside out. I wasn't always a mindful person. I only started to practice mindfulness myself around five years ago and I saw what it was doing to me. So, I was able to bring that. I was also someone who read very late in life; I learned to read not in grade one and not in grade two. I think that the type of teacher I am is reflected in my own personal learning to read. I think I bring the same thing to the mindfulness practice. I share that passion and I model it day after day. I can walk into their class now when they're in grade three and all I have to say is the word "mindful" to them and I see their whole body changes. I'Il put my hand on their shoulder and say, "Take a deep breath." I'Il see kids in the hall looking like their anxiety level has just skyrocketed and I'Il say to them, "Take a breath with me." And I'll breathe in and let it out. Two breaths can take them through any task. It was really interesting, I asked my students this week about when do they use mindfulness outside my classroom and one little girl said, "Oh, right before dictée" (dictée is their French spelling test). We have a signal in the classroom where they go like this [pats the left side of her chest] if they had the same answer so they don't feel badly if everyone is raising their hand and you can only pick one child. So they were all going like this [pats the left side of her chest], "I agree, I agree." So I said, "What do you do?" And she said, "I just take two really deep breaths and then it just settles me down and I can focus on my dictée." And I say, "What happens?" "Oh, I do really well." So, they're making those connections without me having to make it for them. 
What do you think mindfulness practice has done for your teaching?

I've watched kids and been in the classroom for so many years. I have an appreciation for them that has reminded me of the importance of being patient. I believe I've become a much more patient person. I used to always want to "infect" as many people as I could: "What I'm doing has to be done by everybody else." I've stepped back from that and what I've said is what's really important is what's going on today, in this classroom, with the students and I can't be responsible for every teacher in the province. And, I can't be responsible for every child in the province. It really hit me hard last year when I started that month of mindfulness. I reached out to schools around the world and 12 schools joined us for this mindful journey. I was so busy helping everyone around me being mindful, I forgot how important it is to be mindful myself. And I suffered. I really had to regroup and take a step back and say, "How is this possible? I'm the new mindful guru and everyone is counting on me to help them, why isn't it working with me?" I had to think really hard and I came to terms with the fact that I'm to take care of me and if I'm healthy, my students will be healthy.

We have to know that as teachers that if we're passionate, they become passionate. And not by telling them to be passionate, but by showing them. And even with writing, it's "show, don't tell." I can stand up and do mini-lesson after mini-lesson and say, "Why aren't they putting punctuation at the end of sentence? I taught them how, why aren't they doing it?" It's that same model, that same philosophy; it's just another skill. Kids today just need it more and more. The research and statistics are showing that. We can't stop technology; we can't slow it down. It's coming at our students at a very fast pace and technology is just one way that they're getting information from. It's coming from themselves; it's coming from their parents. We want children to succeed and we want them to be the best they can be. I have a saying: "Practice makes it, not perfect, but practice makes it permanent." And that's what we want to make sure.

What would you suggest other teachers should do if they are interested in pursuing mindfulness practices in their classroom?

They need to start themselves. How do we teach writing? By practicing to write. Start off with one minute a day. That's all you start with. Don't take on something bigger because we're not going to succeed. We all have our New Year's resolutions—l'm going to exercise five days a week! [We don't] exercise five days a week and then we don't do it and we stop. Say, "I'm going to take one minute out of my day, consciously and practice mindfulness." You will see it happens so quickly. The results are fast: you don't have to go to the gym for months to see that weight drop. Promise yourself, say to yourself: "It will help you and it will help your students." If a teacher is feeling well, her students are going to feed off of that. We can't guarantee that every child is going to get healthier and feel well if they practice mindfulness, but I've never seen anything where the results happen so quickly. But it has to continue. After the 30 days of the journey, it had to go on, and in my life it did. I'm really fortunate too because I was sitting at a ped day last year in August, we had a speaker and we sat in a three-hour workshop on meditation. In August! This was tough for some, as they had never experienced meditation before. I, on the other hand 
was like, "Oh my god, I'm still on vacation!" I practiced it all summer. The presenter had a screen up about the 30-day "Movember," where men grow beards, and I said to my colleague who is a phys. ed. teacher, "Let's do a mindful challenge with our Cycle One kids." She said, "Barbara, I love it!" We walked in a Cycle One meeting right after and we decided to present it to the Cycle One team and everybody said "yes," which to me was the first time. It was a unanimous decision which to me, I couldn't ignore that. I'm very fortunate that I work with colleagues that, although I have many things that I'm passionate about, they respect me highly when I bring something up that, I think, affected them too. Even though that ped day was hard, it has to be hard for it to be meaningful. I really think that was the trigger. It's part of one of our pillars, mental health and well-being, but to see it in action was something else.

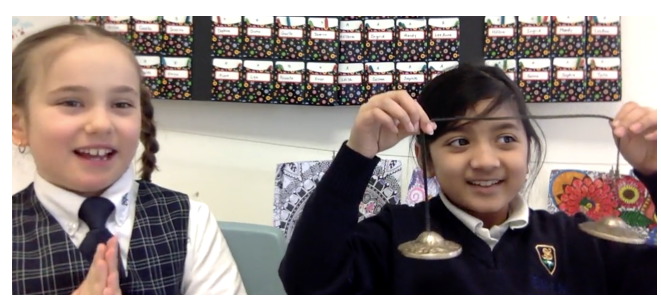

Click here for interview with two students at The Study School. 


\section{References}

DiOrio, R. (Author), \& Wheeler, E. (Illustrator). (2010). What does it mean to be present? Belvedere, CA: Little Pickle Press.

MacLean, K. L. (2009). Moody cow meditates. United States: Wisdom Publications.

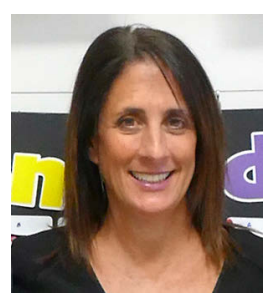

Barbara Kurtzman has been a Grade 1 teacher at The Study School in Montreal for over 25 years. Most recently, she was accepted in McGill's Masters program in the department of Integrated Studies, where she continues to grow professionally and personally. She has been involved in many wonderful initiatives and continues to share her passion with her students, colleagues and parents. She believes some of the interesting aspects of teaching are making sure her students feel like they are part of a community of learners, where it is safe to take risks, and to be grateful for each day.

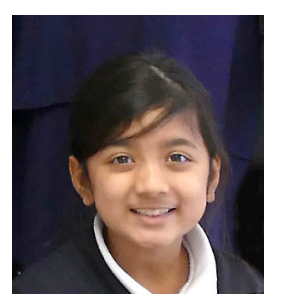

\section{Disha De}

Disha is a wonderful writer. She loves cats, big and small cats. She loves the colour blue, using her iPad, and watching television. She is a girl with a lot of information. She has a great vocabulary and loves to share her ideas with others. Disha is the kind of girl that never gives up!

by: Catherine

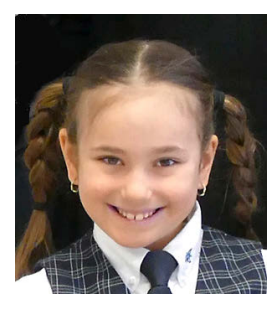

Catherine Latreille

Catherine loves to read. I would say she is a bookworm. She is also good at Math and likes to solve challenging math problems. Catherine has a lot of information that she likes to share with her classmates and teachers. Catherine is also an amazing friend.

by: Disha De 